\title{
How Does Ownership Affect Bank Performance?-The Case Of Indian Commercial Banks
}

\author{
Manjula Kumara Wanniarachchige, PhD candidate, Ritsumeikan Asia Pacific University, Japan \\ Yasushi Suzuki, Ritsumeikan Asia Pacific University, Japan
}

\begin{abstract}
Financial system reforms in recent decades have significantly reshaped the Indian commercial banking system. Despite substantial changes in the ownership and structure of Indian Banking system, fewer reliable studies have been conducted to empirically investigate the effect of ownership on various performance dimensions. Drawing upon experiences of Indian commercial banks during 2002-2009, this study analyzes how state-owned, nationalized and domestic private banks are behind foreign banks, using data envelopment analysis together with three supplementary measures of performance. The findings suggest that the performance of domestic banks has not yet reached the level of foreign banks in terms of both cost and revenue efficiencies. Surprisingly, domestic private banks are the least efficient in the market. Though foreign banks outperform domestic counterparts in multiple aspects, their contribution for spreading banking services beyond metropolitan cities by establishing new branches is trivial and thus they make the least contribution to country's financial deepening.
\end{abstract}

Keywords: bank performance; commercial banks; data envelopment analysis; India; revenue efficiency

\section{INTRODUCTION}

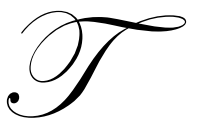

he banking system in India, the largest country in South Asia, has evolved to a new stage with the financial reform initiatives that significantly contributed to the enhancement of its performance. Indian banking system was initially dominated by private banks (Saha \& Ravisankar, 2000) until the dominance was shifted to state-owned banks since 1969 when the government nationalized 14 largest private banks under the Nationalization Act of 1969 (Kumbhakar \& Sarkar, 2003). Second wave of nationalization occurred in 1980 when government nationalized another 6 banks (Roland, 2005). Main objectives of the nationalization were directing credit to priority sectors and expansion of branch network. However, with massive nationalization movements and increased share of government ownership in the financial system, the pre-deregulation era of Indian banking industry was mainly characterized with excessive government interventions, constrained competition and inefficiency etc. portraying a typical case of financial repression. Realizing the inefficient status of the banking and financial sector, the government subsequently initiated series of financial reforms including interest rate deregulation and relaxation of regulation on entry and directed credit. The financial reforms, at the initial stage commencing in 1992, have mainly focused on increasing the role of private banks, opening the market for foreign banks to foster competition, enhancing the competitiveness through addressing issues relating to non-performing assets (NPA) and capital adequacy etc. Moreover, with the intention of further improving the operational conditions and converging with international standards, Indian banking system started implementing the concepts of Basel capital standards in 1992 (Roland, 2005). Similarly, improvement of operational efficiency, quality of customer services, integration of information technology etc. to improve bank profitability and soundness have been the key focus in the later stages commencing in 1998 (see Kumar \& Gulati, 2009; Saha \& Ravisankar, 2000).

As a consequence of these reforms, the Indian banking system changed substantially and the shares of private and foreign banks increased compared to 1970s and 1980s. Nevertheless, despite the slight decline in market 
share, state-owned and nationalized banks still dominate Indian banking system. For example, State Bank of India (SBI) and its associates hold around 27 percent while nationalized banks hold around 52 percent of the market on average during 2002-2009 leaving only 21 percent for foreign and domestic private banks. However, the share of private sector banks was substantially lower during pre-reform period and even in early 1990s. For example, the share held by foreign banks was less than 5 percent on average during the aforesaid period. Even though the market share of privately owned banks is substantially lower, their respective share of profit is disproportionately higher than that of publicly owned banks (Mittal \& Dhade, 2007). On the other hand as illustrated in table 1 domestic private banks and foreign banks collectively have been able to extend 25.5 percent of total loans by employing only 8.7 percent of the total banking industry employees in 2002. This highlights some of the significant differences between the operating conditions of publicly owned banks and privately owned banks. However, with the absorption of necessary skills and technology by publicly owned banks in the light of increased competition in the market such disparities have been largely disappeared by 2009 where privately owned banks have collectively extended 24.7 percent of total loans while employing 21.9 percent of the total banking sector employees.

Table 1: Commercial bank group-wise aggregate statistics in 2002 and 2009

\begin{tabular}{|c|c|c|c|c|c|c|c|c|c|}
\hline \multirow{2}{*}{$\begin{array}{l}\text { Bank } \\
\text { Group }\end{array}$} & \multicolumn{2}{|c|}{ No. of banks } & \multirow{2}{*}{$\begin{array}{l}\text { No. of } \\
\text { offices }\end{array}$} & \multirow{2}{*}{\multicolumn{2}{|c|}{$\begin{array}{l}\text { Number of } \\
\text { Employees }\end{array}$}} & \multirow{2}{*}{\multicolumn{2}{|c|}{$\begin{array}{c}\text { Deposits } \\
\text { (Rs. Billions) }\end{array}$}} & \multirow{2}{*}{\multicolumn{2}{|c|}{$\begin{array}{c}\text { Loans } \\
\text { (Rs. Billions) } \\
\end{array}$}} \\
\hline & Industry & Sample & & & & & & & \\
\hline \multicolumn{10}{|l|}{ March 2002} \\
\hline State Owned Banks & 8 & 7 & 13,681 & 287,245 & $(33.3)$ & 3,511 & $(29.2)$ & 1,646 & $(25.5)$ \\
\hline Nationalized Banks & 19 & 19 & 33,995 & 498,581 & $(57.9)$ & 6,177 & $(51.4)$ & 3,161 & $(49.0)$ \\
\hline Domestic Private Banks & 30 & 16 & 5,578 & 62,438 & $(7.2)$ & 1,694 & (14.1) & 1,164 & $(18.0)$ \\
\hline Foreign Banks & 40 & 8 & 206 & 13,232 & (1.5) & 645 & $(5.4)$ & 486 & $(7.5)$ \\
\hline Total & 97 & 50 & 53,460 & 861,496 & $(100.0)$ & 12,027 & (100.0) & 6,457 & (100.0) \\
\hline \multicolumn{10}{|l|}{ March 2009} \\
\hline State Owned Banks & 7 & 7 & 16,731 & 268,598 & $(28.5)$ & 10,070 & $(24.8)$ & 7,396 & $(24.6)$ \\
\hline Nationalized Banks & 20 & 19 & 40,766 & 466,063 & $(49.5)$ & 21,057 & $(51.8)$ & 15,205 & $(50.7)$ \\
\hline Domestic Private Banks & 22 & 16 & 9,186 & 176,410 & $(18.7)$ & 7,364 & $(18.1)$ & 5,753 & $(19.2)$ \\
\hline Foreign Banks & 31 & 8 & 295 & 30,304 & $(3.2)$ & 2,141 & $(5.3)$ & 1,654 & $(5.5)$ \\
\hline Total & 80 & 50 & 66,978 & 941,375 & $(100.0)$ & 40,632 & $(\mathbf{1 0 0 . 0})$ & 30,009 & $(100.0)$ \\
\hline
\end{tabular}

Notes: Market shares in brackets (percentage)

Source: Statistical tables of Reserve Bank of India

Despite the progress of banking reforms and resulting changes in the banking environment, substantially fewer reliable studies have been conducted to investigate the performance dynamics of Indian commercial banks. Moreover, majority of existing studies are either associated with drawbacks (Sathye, 2003) particularly in the methodology or confined to limited and historical time periods or limited to a particular group of banks. This poses significant doubts about the validity of their findings. Thus, the performance dynamics of Indian commercial banking system remain as an important area to be re-investigated.

In view of the above facts, this study aims first, to estimate performance of Indian commercial banks in various aspects and then, to evaluate the effect of ownership on performance by grouping banks into four categories: namely, state-owned, nationalized, foreign and domestic private banks. To assess the direction of performance changes across time, the convergence of performance is also analyzed. This study prevails over previous studies due to four main aspects. First, to overcome limitations in the literature, this study extends the sample and time frame to cover 50 commercial banks over most recent eight year period. Second, without limiting the analysis to one indicator, the study uses a wide range of performance measures which allow capturing performance changes in multiple dimensions. Third, the study attempts to avoid some model specification issues associated with previous studies due to mixed 'flow' and 'stock' concepts in input-output identification for DEA. Finally, it contributes with its recent estimates on efficiency and guides the bankers and policy makers in improving the performance of Indian commercial banks. 
The paper is organized into five sections where section two provides a review of related literature and section three discusses the methodology. Section four explores the empirical results and discusses key findings. Finally section five concludes the paper with a discussion of implications.

\section{REVIEW OF RELATED LITERATURE}

The underlying arguments pertaining to the effect of ownership on performance is mainly based on the principle-agent framework and the public choice theory to emphasize the importance of management being constrained by capital market discipline (Altunbas, Evans, \& Molyneux, 2001). For instance, one of the main propositions of the public choice theory is that, the state-owned enterprises necessarily poorly perform than their privately-owned counterpart due mainly to political influences. However, managers in private firms have more incentives to pursue owner's objectives than managers in state enterprises have, because monitoring in private capital market is superior to that of government (Figueira, Nellis, \& Parker, 2009). Inevitably, pre-deregulation financial systems are largely owned and controlled by governments of respective countries. The financial deregulation commonly involves privatization of state-owned banks, opening up the market for foreign and domestic private banks and elimination (or relaxation) of other type of frictions that constrain the behavior of the market. The basic proposition underlying such deregulation is that it promotes the competition in the market which eventually forces banks to alter their input mixes and technologies to become more efficient.

Moreover, property rights approach also holds that the form of ownership is a predominant determinant of performance of different organizations (Starr, 1988). Transferability of ownership in privately held firms makes costs and rewards to be accrued more directly to responsible individuals. In contrast, inability of each individual owner to transfer their respective shares of ownership in a public enterprise inhibits inexpensive detection and rectification of poor management practices (Davies, 1977). Thus, private firms are expected to be more efficient than state-owned enterprises. This argument also supports financial liberalization and enhancement of private sector participation to uplift the performance in the banking systems while at the same time providing a platform for the ownership-performance debate.

Among few available studies in Indian context, Bhattacharyya, Lovell, and Sahay (1997) claim publicly owned banks to be the most efficient followed by foreign and domestic private banks respectively. These findings are not only quite contrast to theoretical justifications but also less applicable in the current context due to several reasons. First, the study is based on data during 1986-1991 which is too historical and covers basically the prereform period where foreign and domestic private banks did not play a significant role. Second, the outputs of their study consist of advances, investments and deposits following the production approach ${ }^{1}$. Though the treatment of deposits as an output is acceptable in the early stages of Indian banking system where one of the main objectives was to mobilize deposits, in the current context it deems to be inappropriate in a deregulated environment where intermediation approach is more appropriate. Third, they identify outputs based on the 'stock' concept whereas inputs (interest expenses and operating expenses) based on the 'flow' concept. ${ }^{2}$ Finally, their data set consists of an unbalanced panel, due to which the relative efficiency scores of Data Envelopment Analysis (DEA) might be substantially affected as composition of sample units change (i.e. when new banks enter into the sample or existing banks drop out of the sample).

Saha and Ravisankar (2000) report public sector banks in general have gained efficiency during 1992-1995. This can be largely attributed to the increased competition resulted from the financial reforms initiated since 1992. Their study also flaws in many aspects. First, it is confined to publicly owned banks. Second, the study covers only the initial phase of financial reforms and the findings are largely outdated by now. Third, the model mixes 'stock' and 'flow' concepts while relying basically on the production approach which is not appropriate in the context of financial intermediaries. Further, their estimation approach and the selection of inputs and outputs remain vague and seemingly lack theoretical justification.

\footnotetext{
${ }^{1}$ A brief discussion on the production and intermediation approaches is available in the methodology section. For more details see Freixas and Rochet (1997).

2 The 'flow' concept expresses inputs and outputs as some amount per a unit of time where as the 'stock' concept expresses inputs and outputs as amounts at a particular point in time (see Colwell \& Davis, 1992).
} 
Sathye (2003) based on his study on Indian banks during 1997-98 financial year suggests that domestic private banks to be less performing than state owned and foreign banks. But his study confines itself to a narrow time frame, one financial year. Further, a mixing of 'flow' and 'stock' concepts could be observed in model B regarding inputs and outputs. A more recent study conducted over 1997-2003 period by Kumar and Gulati (2009), mainly based on DEA, reports that technical efficiency of public sector banks has been slightly increased, and find evidences for convergence of efficiency among public sector banks. But their study is confined to public sector banks and thus fails to explain performance dynamics of other groups of banks. In their study also, a mixture of 'flow' and 'stock' concepts can be observed regarding input and output identification for DEA.

The literature reviewed here is rather illustrative than exhaustive. The findings in majority of the Indian banking studies claim that publicly owned banks are superior to their privately owned counterpart. Moreover, existing banking studies reveal the diversity of approaches and techniques used in modeling bank activities and estimating efficiency together with their respective limitations. Not surprisingly, this has laid the foundation for diverse findings.

\section{METHODOLOGY}

Along with the recent popularity of x-efficiency literature, the estimation of efficiency of financial intermediaries like banks has followed two main approaches (i.e. parametric and non-parametric) that rely on frontiers in estimating performance. Among parametric approaches, stochastic frontier approach is widely used while DEA is widely adopted under non-parametric approaches. Importantly, the efficiency estimates are highly sensitive to the technique and the approach used in estimating and modeling banking activities (Saha \& Ravisankar, 2000). Due mainly to its popularity in banking studies and flexibility in application, this study relies mainly on DEA which is further supplemented by certain other conventional performance measures.

The study focuses on 80 Indian commercial banks under various ownership groups during 2002-2009. However, banks with only three or less branches (dropped due to their extremely limited role in the industry), banks that have been subjected to mergers or acquisitions during the study period, banks that have commenced or ceased operations within the study period and banks for which data is substantially missing were dropped from the sample to maintain the consistency of the sample across different time periods. Thus, as shown in table 1 , the final data set consists of a balanced panel of 50 banks over eight years resulting in 400 bank year observations. The sample comprises 7 state-owned banks, 19 nationalized banks, 16 domestic private banks and 8 foreign banks (grouping is done based on the classification by Reserve Bank of India, the central bank). It should be noted that, in this study, state-owned banks and nationalized banks are sometimes collectively referred to as publicly owned banks while state-owned banks, nationalized banks and domestic private banks are sometimes collectively referred to as domestic banks. Performance is mainly estimated based on DEA and is supplemented by three other relatively conventional performance measures: namely, Return on Assets (ROA), NPA ratio, and extent of branch network.

In the second stage Analysis of Variance (ANOVA) is used to evaluate performance variations among various ownership groups. ROA, a popular traditional measure of performance, is used to compare with DEA efficiency scores. NPA ratio and extent of branch network etc. are used to capture other aspects of performance and to explain performance variations. To investigate the status of convergence of efficiency within the Indian commercial banking system, this study calculates $\sigma$-convergence following the same approach as Kumar and Gulati (2009). $\sigma$-convergence exists when the dispersion among bank efficiency scores tends to decrease across the time. In other words, existence of $\sigma$-convergence implies that the differences between efficient banks and inefficient banks are declining over time and tend to converge. For this purpose, the study uses regression model illustrated in equation 1, in which $C V$ denotes the coefficient of variation, $\alpha$ stands for intercept while, the coefficient $(\sigma)$ denotes the existence of $\sigma$-convergence. Further, $t$ and $\varepsilon$ respectively denotes time and random error.

$\operatorname{In}(C V)=\alpha+\sigma t+\varepsilon_{t}$ 


\subsection{Data Envelopment Analysis (DEA) -Slack Based Measure (SBM)}

Traditionally, performance measurement of financial institutions was mainly limited to various financial ratios. Ability of such ratios, however, to capture a comprehensive picture of performance is limited. Moreover, such measures do not adequately focus on the long-run performance aspects. Thus, the recent attention of researchers has been shifted towards more sophisticated approaches like frontier efficiency (Sathye, 2003). Among various frontier efficiency measurement techniques, DEA has been emerged as a leading tool due to its advantages and flexibility (Colwell \& Davis, 1992). DEA is a non-parametric, mathematical programming technique first introduced by Charnes, Cooper, and Rhodes (1978) and subsequently extended and widely applied by various authors (Coelli, 1996). DEA uses piece-wise liner technology to establish efficient frontier relative to which the efficiency of various Decision Making Units (DMU) are estimated. Thus, relative efficiency scores generated by DEA ranges between 0 and 1 and comparable only within the sample.

DEA has several advantages over other non-parametric and parametric approaches. First, DEA enables the estimation of efficiency in complex production entities with multiple inputs and outputs (Moritaa, Hirokawaa, \& Zhub, 2005). Second, it allows the analyst to choose inputs and outputs depending on managerial concerns (Sathye, 2003). Third, DEA is unit invariant allowing the measurement of different inputs and outputs using different units of measures. This avoids the difficulties that arise when attempting to convert input-output measurements into a common unit of measure. Fourth, DEA does not assume a particular production technology (Avkiran, 2006). Finally, DEA uses maximum of a ratio of weighted outputs to weighted inputs where the weights are determined by the model so that it gives maximum possible score for each DMU and hence does not require a prior specification of weights (Cooper, Seiford, \& Tone, 2006). Thus, it is substantially flexible and has emerged as a valuable benchmarking tool compared to techniques like stochastic frontier approach etc. (Avkiran, 2006). DEA, however, is not free of limitations. Its high sensitivity to data errors and outliers, inability capture random effects and inability of DEA efficiency estimates to be compared outside the sample remain as caveats. Thus, it is recommended to compare DEA efficiency measures with other performance measures and to investigate significant differences, if any (see Sathye, 2003).

Among various DEA models this study uses Slack Based Measure (SBM), first proposed by Tone (2001), due to its attractiveness over other traditional DEA models. In its design, SBM efficiency score never exceeds the efficiency score generated by CCR model. Thus, a DMU is SBM-efficient if and only if it is CCR-efficient. The reason is that, SBM deals directly with slacks (input excesses and output shortages) whereas traditional CCR and BCC do not consider such slacks. Further, SBM is unit invariant and monotone with respect to slacks (Tone, 2001). Thus, in this sense while SBM is compatible with other DEA models, it shows a sharp contrast to them.

\subsection{DEA Inputs And Outputs}

Identification of inputs and outputs of financial intermediaries like banks is not straightforward (Avkiran, 2006; Colwell \& Davis, 1992) and a matter of long standing debate in the literature (Sathye, 2003). There are two main approaches for identification of outputs and inputs: namely, production approach and intermediation approach (see Freixas \& Rochet, 1997). The production approach tends to view a bank as an entity that produces deposits and loans using capital and labor whereas intermediation approach views a bank as an entity that intermediates financial assets between savers and investors. However, intermediation approach deemed more suitable for indentifying inputs and outputs for banks and have been adopted by large number of studies though, non-credit outputs have been treated plainly in the intermediation approach (Colwell \& Davis, 1992). Moreover, intermediation approach is consistent with existing commercial bank studies (Worthington, 2000).

This study adopts the intermediation approach in identifying inputs and outputs. It is commonly visible in the literature that most of the banking studies that adopted DEA have mixed 'flow' and 'stock' concepts in identifying inputs and outputs. To overcome such limitations, this study employs two models where model 1 is based on 'flow' concept, in which all variables are measured as amounts per a unit of time (during a year), and model 2 is based on the 'stock' concept, in which all variables are measured as amounts at a particular point in time (at the end of the financial year). The model 1 draws upon Drake, Hall, and Simper (2009), Hadad et al. (2008), and Sathye (2003) and aligns with revenue/profit based efficiency initially proposed by Berger and Mester (1997). In 
contrast, model 2 draws upon Kirkwood and Nahm (2006 model A), Sathye (2001), and Sturm and Williams (2004) and relies on traditional cost efficiency concept. Thus, the input and output identification in this study is highly consistent with the literature but avoids the critical limitations associated with past studies. Table 2 illustrates input and output specifications for DEA models. With the initiatives of deregulation, an increase of off-balance sheet items such as commissions is commonly observable. Ignoring such activities results in understatement of bank outputs. Thus, to account for these activities non-interest income is included as an output in DEA model 1.

Table 2: DEA input, output specification

\begin{tabular}{ll}
\hline Outputs & \\
$\begin{array}{l}\text { Interest income } \\
\text { Non-interest income }\end{array}$ & Interest expenses \\
& $\begin{array}{l}\text { Personal expenses } \\
\text { Other operating expenses }\end{array}$ \\
\hline Model 2 & Inputs \\
\hline Outputs & Value of deposits \\
Value of loans and advances & Number of employees \\
Value of investments & Value of fixed assets \\
& \\
Input prices & Interest expenses divided by the value of deposits \\
Cost of loanable fund & Personnel expenses divided by the number of employees \\
Cost of labor & Other operating expenses divided by the value of fixed assets \\
Cost of physical capital &
\end{tabular}

The efficiency scores are calculated for each period separately. Thus, the efficiency scores derived in this study represents a measure relative to the efficient frontier of that particular time period (instead of any grand frontier for entire sample period). One of the objectives of such estimation is to avoid the impact of macro factors that simultaneously affect all the banks in each time period and hence, the estimates in this study are superior to efficiency estimates based on a grand frontier particularly when the macro economic conditions are volatile. Further, to achieve maximum discrimination of DMUs, in terms of efficiency scores, the constant returns to scale (CRS) assumption is held in this study. When variable returns to scale is used only similar sized DMUs are compared and hence, fail to discriminate less performing small scale DMUs. However, due to this assumption, the impact of scale on performance of banks is not properly accounted for in this study.

\section{EMPIRICAL FINDINGS AND DISCUSSIONS}

The study employed two DEA models to estimate SBM efficiencies of 50 Indian commercial banks over eight year period ranging from 2002 to 2009. One of the interesting observations is that both DEA models suggest that the efficiency variation in the banking system is increasing during 2002-2009. For example, as illustrated in table 3, the mean efficiency score is decreasing while the standard deviation is increasing on a continuous basis showing the opposite of convergence of bank performance. To statistically test the status of convergence of efficiency among various banks the study calculated $\sigma$-convergence as discussed in section 3 by regressing $\log$ of the coefficients of variations of revenue and cost efficiencies respectively onto time variable in two different regressions. Results of both regression are statistically significant for both revenue efficiency $[R=.80, F(1,6)=$ $35.8, p<.01]$ and cost efficiency $[R=.93, F(1,6)=10.4, p<.05]$ and explains 85 percent and 63 percent of the variations respectively. Coefficients of both regressions (.010 and .047) were significant at $p<0.05$ and remain positive indicating the opposite of $\sigma$-convergence ( $\sigma$-divergence).

With respect to cost efficiency, the $\sigma$-divergence is mainly reflected in the increase of performance differences across different ownership groups where only domestic private banks showed a within group $\sigma$ divergence. In contrast, in terms of revenue efficiency, the performance divergence is reflected not only in the intergroup increase of performance differences but also in the intra-group increase of performance differences within 
both nationalized banks and domestic private banks. Importantly a sign of statistically significant $\sigma$-convergence in performance could not be found within any of the ownership groups. The performance divergence is serious within the domestic private banks as the differences are increasing in terms of both revenue efficiency as well as cost efficiency. This could be one of the reasons for reducing the number of domestic private banks from 30 in 2002 to 22 in 2009 (see table 1) as the competition compels inefficient banks to withdraw from the industry or to merge with strong banks. For example, Alam (2001) state that banks not allocating its resources efficiently would perish unless they could become more like their efficient competitors.

Table 3: Descriptive statistics of efficiency scores

\begin{tabular}{|c|c|c|c|c|c|c|c|}
\hline \multicolumn{4}{|c|}{ Model 1: Cost Efficiency } & \multicolumn{4}{|c|}{ Model 2: Revenue/Profit Efficiency } \\
\hline Year & Mean & Std. Deviation & $\mathrm{CV}$ & Year & Mean & Std. Deviation & $\mathrm{CV}$ \\
\hline $2001-02$ & .701 & .252 & 0.36 & $2001-02$ & .810 & .164 & 0.20 \\
\hline $2002-03$ & .740 & .248 & 0.34 & $2002-03$ & .823 & .165 & 0.20 \\
\hline 2003-04 & .713 & .239 & 0.33 & 2003-04 & .800 & .172 & 0.21 \\
\hline 2004-05 & .732 & .252 & 0.34 & 2004-05 & .817 & .191 & 0.23 \\
\hline 2005-06 & .672 & .248 & 0.37 & 2005-06 & .719 & .255 & 0.36 \\
\hline 2006-07 & .691 & .254 & 0.37 & 2006-07 & .686 & .216 & 0.31 \\
\hline 2007-08 & .691 & .268 & 0.39 & 2007-08 & .536 & .198 & 0.37 \\
\hline 2008-09 & .673 & .275 & 0.41 & 2008-09 & .586 & .221 & 0.38 \\
\hline
\end{tabular}

$\mathrm{CV}=$ Coefficient of Variation

Table 4: ANOVA results-Significant mean differences

\begin{tabular}{lccl}
\hline Revenue Efficiency & & & \\
\hline Bank Group & Mean & $\begin{array}{c}\text { Std. } \\
\text { Deviation }\end{array}$ & $\begin{array}{c}\text { Mean } \\
\text { Differences }\end{array}$ \\
\hline Foreign & .843 & .217 & $\mathrm{~N}^{*}, \mathrm{P}^{*}, \mathrm{~S}^{* *}$ \\
Nationalized & .710 & .196 & $\mathrm{~F}^{*}$ \\
Private & .676 & .246 & $\mathrm{~F}^{*}$ \\
State & .722 & .207 & $\mathrm{~F}^{* *}$ \\
\hline ROA & & & \\
\hline Foreign & 1.721 & 1.061 & $\mathrm{~N}^{*}, \mathrm{P}^{*}, \mathrm{~S}^{*}$ \\
Nationalized & .971 & .420 & $\mathrm{~F}^{*}$ \\
Private & .937 & .728 & $\mathrm{~F}^{*}$ \\
State & 1.018 & .257 & $\mathrm{~F}^{*}$ \\
\hline Branch network & & & \\
\hline Foreign & .013 & .010 & $\mathrm{~N}^{*}, \mathrm{P}^{*}, \mathrm{~S}^{*}$ \\
Nationalized & .673 & .392 & $\mathrm{~F}^{*}$ \\
Private & .553 & .505 & $\mathrm{~F}^{*}$ \\
State & .580 & .302 & $\mathrm{~F}^{*}$ \\
\hline
\end{tabular}

\begin{tabular}{|c|c|c|c|}
\hline \multicolumn{4}{|l|}{ Cost Efficiency } \\
\hline Bank Group & Mean & $\begin{array}{c}\text { Std. } \\
\text { Deviation }\end{array}$ & $\begin{array}{c}\text { Mean } \\
\text { Differences }\end{array}$ \\
\hline Foreign & .897 & .202 & $\mathrm{~N}^{*}, \mathrm{P}^{*}$ \\
\hline Nationalized & .680 & .208 & $\mathrm{~F}^{*}, \mathrm{P}^{*}, \mathrm{~S}^{*}$ \\
\hline Private & .550 & .242 & $\mathrm{~F}^{*}, \mathrm{~N}^{*}, \mathrm{~S}^{*}$ \\
\hline State & .883 & .179 & $\mathrm{~N}^{*}, \mathrm{P}^{*}$ \\
\hline \multicolumn{4}{|l|}{ Net-NPA Ratio } \\
\hline Foreign & 1.018 & 1.653 & $\mathrm{~N}^{*}, \mathrm{P}^{*}, \mathrm{~S}^{* *}$ \\
\hline Nationalized & 2.608 & 2.828 & $\mathrm{~F}^{*}$ \\
\hline Private & 2.884 & 2.607 & $\mathrm{~F}^{*}, \mathrm{~S}^{* *}$ \\
\hline State & 1.870 & 1.699 & $\mathrm{~F}^{* *}, \mathrm{P}^{* *}$ \\
\hline \multicolumn{4}{|l|}{ Notes: } \\
\hline \multicolumn{4}{|c|}{$\begin{array}{l}\text { N-Nationalized; P- Private; S- State; F-Foreign; } \\
* \text { and } * * \text { indicates groups with significant mean } \\
\text { differences at } .01 \text { and } .05 \text { level respectively }\end{array}$} \\
\hline
\end{tabular}

Analysis of variance (ANOVA) was conducted to evaluate the effect of ownership on the level of performance of banks measured in terms of two DEA efficiency measures and other supplementary performance measures. Banks were categorized in to four groups: namely, state-owned, nationalized, domestic private and 
foreign banks. Table 4 illustrates results of ANOVA where the groups between which significant mean differences can be observed are also indicated. For instance, foreign banks have recorded a mean revenue efficiency score of 0.843 and that score is significantly different (higher) to that of both nationalized banks $(\mathrm{N})$ and domestic private banks (P) at 1 percent level and also to that of state-owned banks (S) at 5 percent level.

Foreign banks are the most revenue-efficient followed by state-owned, nationalized and domestic private banks respectively. ANOVA shows a significant effect of ownership characteristics on the revenue efficiency of banks, $\left[F(3,400)=8.55, p<.01, \eta^{2}=.06\right]$. Post hoc analysis was performed based on Dunnett $C$ tests, relaxing homogeneity of variance assumption, to evaluate exact differences between groups. The analysis shows that the mean performance difference between foreign banks and other banks were statistically significant $(p<.05)$ whereas no statistically significant performance differences could be observed among state-owned, nationalized and domestic private banks in terms of revenue efficiency. Foreign banks rank first in terms of the cost efficiency also followed by state-owned, nationalized and domestic private banks respectively where significant effect of ownership could be observed, $\left[F(3,400)=52.50, p<.01, \eta^{2}=.29\right]$. Similar post hoc analysis shows that cost efficiency differs significantly among each group $(p<.01)$ except for between foreign banks and state-owned banks where significant difference could not be observed.

To compare the DEA efficiency estimates with traditional financial ratio based performance measures, the effect of ownership on Return on Assets (ROA) and the ratio of Non-Performing Assets (NPA) ratios were also analyzed. The mean ROA were highest for foreign banks followed by state-owned, nationalized and domestic private banks. The ANOVA suggests a strong effect of ownership on the ROA, $\left[F(3,400)=24.22, p<.01, \eta^{2}=\right.$ .16]. ROA of foreign banks significantly differs from other categories $(p<.01)$. No other differences could be observed in terms of ROA among other groups. Foreign banks outperformed all other categories of banks in terms of NPA whereas state-owned, nationalized and domestic private banks recorded relatively higher NPA ratios respectively, suggesting a strong effect from ownership $\left[F(3,400)=9.51, p<.01, \eta^{2}=.07\right]$. Post hoc analysis reveals that NPA ratio of foreign banks were significantly different form all other categories while a significant difference between NPA ratios of state-owned banks and domestic private banks could also be observed $(p<.05)$. Statistically significant difference in NPA ratio could not be observed between state-owned and nationalized banks, and between private and nationalized banks.

In terms of the extent of financial services expansion, spread of the branch network also can be considered as a performance measure. $\mathrm{Wu}$ (2005) also states that branch network expansion can be considered as a quality adjusted performance measure though it may have a negative impact on the cost efficiency. Further, Burgess and Pande (2003) report that expansion of rural branch network in India has contributed to lower poverty and improve non-agricultural output. Thus, the effect of ownership on the branch network expansion was analyzed. First, the number of branches of each bank was adjusted for its size by dividing it by the invested capital (capital and reserves). The main objective of adjusting number of branches for size of the bank is to see whether some banks, being relatively large, refrain from extending branch network. In other words, it is worth assessing whether a bank has expanded its branch network sufficiently relative to its absolute size in the industry rather than mere number of branches that each bank has. In this sense, nationalized banks accounted for highest branch expansion followed by state-owned, private and foreign banks respectively. ANOVA suggests a strong effect of ownership on branch network expansion, $\left[F(3,400)=44.31, p<.01, \eta^{2}=.25\right]$. Post hoc Dunnett $C$ test reveals that foreign banks account for substantially fewer branches than all other categories of banks $(\mathrm{p}<.01)$. No other differences were found.

Consistent with the available literature and underling theoretical concepts, the findings of this study suggests that foreign banks outperform domestic banks except in terms of branch network expansion. Bhattacharyya, et al. (1997) attribute this in part to the ability for foreign banks in efficiently expanding its branch network within metropolitan areas while not having to extend into rural areas. This gives foreign banks an opportunity to effectively control cost and thoroughly focus on profit maximizing objective yet make least contribution to expansion of banking services beyond main cities.

The lack of profitability of publicly owned banks, on the one hand, can be still attributed to management inefficiencies, priority sector lending and lack of proper manpower planning etc. On the other hand, their main 
objective is not profit maximization as they are more focused on the expansion of banking services towards rural and semi-urban areas, supporting priority sectors and promoting domestic savings etc. For instance, SBI and its associates, since its inception, are entrusted with the objective of delivering banking services to neglected sectors by other financial institutions (Kumbhakar \& Sarkar, 2003). With the initiatives of nationalization this was further intensified. As a result the proportion of commercial banks located in rural areas reached around 45 percent in 1990s compared to around 10 percent in the pre-nationalization era (Sathye, 2003). Thus, publicly owned banks account for highest number of branches and relatively higher employment ratios. However, with strong government support and long history in the industry, they have been able to retain their competitiveness by attracting large pools of deposits at a relatively lower cost and extend large amount of loans capitalizing on their extended branch network.

Most surprising finding is that domestic private banks were found to be the least performing among various ownership groups. Moreover, private banks have not made enough contribution to the expansion of branch network (see also Mittal \& Dhade, 2007). Thus, it appears that the domestic private commercial banks have been effectively marginalized due to strong technological pressure from foreign banks and scale pressures from state-owned banks.

\section{CONCLUSIONS AND IMPLICATIONS}

The objective of this study was to analyze how state-owned, nationalized and domestic private banks are behind foreign banks, using data envelopment analysis together with three supplementary measures of performance. The findings suggest a strong influence from the ownership characteristics on the performance. Domestic banks, particularly state-owned and nationalized banks, play a vital role in extending the branch network in India and spreading the banking services beyond metropolitan areas though their performance has not yet reached the level of foreign banks. Furthermore, domestic private banks perform least efficiently in the market whereas foreign banks are the most efficient among various categories of banks in terms of both revenue and cost efficiency. This might be particularly due to relatively small scale of domestic private banks compared to state-owned and nationalized banks and technologically backwardness compared to foreign banks in addition to higher operating expenses and higher NPA ratios which are common to all domestic banks. However foreign banks contribute least to the spread of bank services through the expansion of branch network beyond metropolitan areas. Moreover, in quite contrast to findings of some of the previous studies this study finds that the performance among different ownership groups (even within some ownership groups) in India tend to diverge rather than converge.

The findings of this study are in consensus with the theory and majority of the ownership-performance studies (particularly outside India) except for the situation in domestic private banks. For instance, foreign banks which are subjected to higher level of capital market discipline in the light of developed international capital markets have higher incentives to be efficient. In contrast, publicly owned banks (i.e. state-owned and nationalized banks) which are not subjected to direct capital market discipline lacks incentives to be efficient. However, it is apparent that other factors like strong government support, scale, and learning effect resulted from long experience create opportunities for publicly owned banks to be competitive. Relatively underdeveloped domestic capital markets have been failed to create incentives to make domestic private banks efficient; and the lack of infrastructure, technological backwardness etc. have further curtailed the operations of domestic private banks.

Controlling employment costs, other operating expenses and NPA remain as key challenges to be immediately addressed by domestic banks. There are signs that performance gaps among domestic private banks in particular are widening. This trend, if continued, can cause smaller inefficient domestic banks to disappear from the market leading the market to be less competitive. Domination of the banking system by state-owned and nationalized banks might affect negatively on the improvement of efficiency as it effectively curtail the competition in the market while constraining the growth of domestic private banks in particular. Thus, strong well focused initiatives for strengthening domestic private banks are vital for the long-term success of Indian commercial banking industry.

\section{AUTHOR INFORMATION}

Manjula K. Wanniarachchige is currently a PhD candidate at the Graduate School of Asia Pacific Studies of Ritsumeikan Asia Pacific University, Japan. He received the BBA degree from the University of Ruhuna, Sri Lanka, 
and MBA degree from the Ritsumeikan Asia Pacific University, Japan. Since 2006, he is working as a faculty member in the faculty of Management and Finance of the University of Ruhuna in Sri Lanka. His research interest is mainly concerned with financial intermediation and performance of banks.

Yasushi Suzuki is a Professor at the Graduate School of Management, Ritsumeikan Asia Pacific University, Oita, Japan. He has an undergraduate degree from Waseda University and a doctorate from the University of London. His main work is on the institutional political economy of financial development, and he has published on the Japanese financial system as well as on financial fragility, credit risk monitoring and bank rent effects in South and East Asia. His work has appeared in Review of Political Economy, International Review of Comparative Public Policy, AsianPacific Economic Literature, and Communist and Post-Communist Studies.

\section{REFERENCES}

1. Alam, I. M. S. (2001). A Nonparametric Approach for Assessing Productivity Dynamics of Large U.S. Banks. Journal of Money, Credit and Banking, 33(1), 121-139.

2. Altunbas, Y., Evans, L., \& Molyneux, P. (2001). Bank Ownership and Efficiency. Journal of Money, Credit and Banking, 33(4), 926-954.

3. Avkiran, N. K. (2006). Developing Foreign Bank Efficiency Models for DEA Grounded in Finance Theory. Socio-Economic Planning Sciences, 40, 275-296.

4. Berger, A. N., \& Mester, L. J. (1997). Inside the Black Box: What Explains Differences in the Efficiencies of Financial Institutions? Journal of Banking \& Finance, 21, 895-947.

5. Bhattacharyya, A., Lovell, C. A. K., \& Sahay, P. (1997). The Impact of Liberalization on the Productive Efficiency of Indian Commercial Banks. European Journal of Operational Research 98, 332-345.

6. Burgess, R., \& Pande, R. (2003). Do rural banks matter? Evidence from the Indian social banking experiment. LSE STICERD research paper no. DEDPS 40. http://ssrn.com/abstract_id=1127009. Retrived on 15 February 2010.

7. Charnes, A., Cooper, W. W., \& Rhodes, E. (1978). Measuring the efficiency of decision making units. European Journal of Operational Research, 2, 429-444.

8. Coelli, T. (1996). A Guide to DEAP Version 2.1: A Data Envelopment Analysis (Computer) Program. CEPA Working Paper 96/08.

9. Colwell, R. J., \& Davis, E. P. (1992). Output and Productivity in Banking. Scandinavian Journal of Economics, 94, 111-129.

10. Cooper, W. W., Seiford, L. M., \& Tone, K. (2006). Data Envelopment Analysis : A Comprehensive Text with Models, Applications, References, and DEA-Solver Software. Boston: Springer.

11. Davies, D. G. (1977). Property Rights and Economic Efficiency: The Australian Airlines Revisited. Journal of Law and Economics, 20(1), 223-226.

12. Drake, L., Hall, M. J. B., \& Simper, R. (2009). Bank modelling methodologies: A comparative nonparametric analysis of efficiency in the Japanese banking sector. Journal of International Financial Markets, Institutions and Money, 19, 1-15.

13. Figueira, C., Nellis, J., \& Parker, D. (2009). The effects of ownership on bank efficiency in Latin America. Applied Economics, 41(18), 2353-2368.

14. Freixas, X., \& Rochet, J. C. (1997). Microeconomics of Banking. Cambridge, Massachusetts, London, England: The MIT Press.

15. Hadad, M. D., Hall, M. J. B., Kenjegalieva, K., Santoso, W., Satria, R., \& Simper, R. (2008). Banking Efficiency and Stock Market Performance: An Analysis of Listed Indonesian Banks. Departmental Working Paper,Department of Economics, Loughborough University.

16. Kirkwood, J., \& Nahm, D. (2006). Australian Banking Efficiency and Its Relation to Stock Returns. The Economic Record, 82, 253-267.

17. Kumar, S., \& Gulati, R. (2009). Did efficiency of Indian public sector banks converge with banking reforms? International Review of Economics, 56(1), 47-84.

18. Kumbhakar, S. C., \& Sarkar, S. (2003). Deregulation, Ownership, and Productivity Growth in the Banking Industry: Evidence from India. Journal of Money, Credit and Banking, 35(3), 403-424.

19. Mittal, M., \& Dhade, A. (2007). Profitability and Productivity in Indian Banks: A Comparative Study. AIMS International Journal of Management, 1(2), 137-152. 
20. Moritaa, H., Hirokawaa, K., \& Zhub, J. (2005). A slack-based measure ofef ficiency in context-dependent data envelopment analysis. Omega, 33357 - 362.

21. Roland, C. (2005). Banking Sector Liberalization in India. Paper presented at the 9th Capital Markets Conference, Indian Institute of Capital Markets, Mumbai, India.

22. Saha, A., \& Ravisankar, T. S. (2000). Rating of Indian commercial banks: A DEA approach. European Journal of Operational Research, 124 187-203.

23. Sathye, M. (2001). X-efficiency in Australian Banking: An Empirical Investigation. Journal of Banking and Finance, 25, 613-630.

24. Sathye, M. (2003). Efficiency of banks in a developing economy: The case of India. European Journal of Operational Research, 148(3), 662-671.

25. Starr, P. (1988). The Meaning of Privatization. Yale Law and Policy Review, 6, 6-41.

26. Sturm, J.-E., \& Williams, B. (2004). Foreign Bank Entry, Deregulation and Bank Efficiency: Lessons from the Australian Experience. Journal of Banking and Finance, 28, 1775-1799.

27. Tone, K. (2001). A Slacks-Based Measure of Efficiency in Data Envelopment Analysis. European Journal of Operational Research, 130(3), 498-509.

28. Worthington, A. C. (2000). Cost Efficiency in Australian Non-Bank Financial Institutions: A NonParametric Approach. Accounting and Finance, 40(1), 75-97.

29. Wu, S. (2005). Productivity and Efficiency Analysis of Australia Banking Sector under Derregulation Proceedings of the Australian Conference of Economists 2005 (pp. 1-43). Melbourne: University of Melbourne/Conference Maker. 
NOTES 